\title{
ESSAY KAJIAN KRONOLOGIS DAN DAMPAK PENGGUNAAN DAN PERKEMBANGAN TEKNOLOGI INFORMASI
}

\author{
Nurfajrin Astria \\ Mahasiswa Magister Ilmu Komunikasi Angkatan VII Universitas Diponegoro \\ nurfajrinastria@gmail.com
}

\begin{abstract}
Today's globalization has enabled humans to communicate in forms we never imagined before. Changes that help humans to convey and disseminate information over time. Advances in information technology is evolving following the progress of the times. For example, in ancient times people use bedug as a communication tool for time reminder. However, as the era of society began to create sophisticated electronic devices such as telephones as a means of communication at close range and distance. Simultaneously with a variety of technologies found to support information leading to the development of information technology so rapidly, where any information that exist in this part of the world we can get with a relatively short time. Due to the increased capability in the field of technology and because the equipment becomes cheaper and more powerful and easy to carry along with the development of computer applications that cause the rapid development of information.
\end{abstract}

Keywords: Communication, impact, information technology

Abstrak: Globalisasi dewasa ini telah memungkinkan manusia berkomunikasi dalam bentuk-bentuk yang tidak pernah kita bayangkan sebelumnya. Perubahan yang membantu manusia dalam menyampaikan dan menyebarluaskan informasi dari waktu ke waktu. Kemajuan teknologi informasi ini berkembang mengikuti kemajuan zaman. Misalnya saja pada zaman dahulu masyarakat menggunakan bedug sebagai alat komunikasi untuk pengingat waktu. Namun seiring berkembangnya zaman masyarakat mulai menciptakan alat-alat elektronik canggih seperti telepon sebagai alat komunikasi jarak dekat maupun jarak jauh. Sekaligus dengan ditemukan berbagai macam teknologi yang tentu mendukung informasi menyebabkan perkembangan teknologi informasi yang demikian pesat, dimana setiap informasi yang ada di belahan dunia ini dapat kita dapatkan dengan waktu yang relatif singkat. Karena dengan kemampuan yang meningkat dalam bidang teknologi dan karena peralatan menjadi lebih murah dan lebih kuat serta mudah dibawa dengan disertai perkembangan aplikasi komputer yang menyebabkan perkembangan informasi semakin cepat.

Kata Kunci:Komunikasi, dampak, Tekhnologi informasi

\section{PENDAHULUAN}

Tahun ini dapat dikatakan sebagai tahun paling bersejarah bagi perkembangan teknologi, informasi, dan komunikasi. Perkembangan peradaban manusia ini diiringi dengan perkembangan cara penyampaian informasi (yang selanjutnya kita kenal dengan istilah teknologi informasi komunikasi), dimulai dari gambar-gambar yang tidak bermakna di dinding gua, peletakan tonggak sejarah prasasti, sampai diperkenalkan dunia informasi yang kita kenal dengan nama internet. Diketahui teknologi informasi komunikasi di masa lampau (masa dimana masyarakat belum mengenal teknologi) difungsikan suntuk suatu metode melakukan pengenalan terhadap bentuk-bentuk yang terlihat dan dikenali hal itu terbukti dengan berburu binatang buruan. Pada masa itu, bentuk komunikasi hanya terbatas pada bentuk suara, dengusan dan isyarat anggota badan atau bedug untuk pengingat waktu.

Selanjutnya perkembangan teknologi yaitu mulai diciptakan dan dikreasikan alat-alat yang dapat menimbulkan dan menghasilkan suara serta bunyi-bunyian seperti halnya 
gendang, terompet, asap dan isyarat-isyarat lainnya. Seperti dewasa ini, banyak sekali perubahan yang terjadi di bidang komunikasi. Mulai dari bentuk komunikasi sederhana sampai pada komunikasi elektronik. Membuat kita dengan mudah berinteraksi dengan cepat menggunakan teknologi informasi yang tentu memungkinkan kita berinteraksi dengan orang lain di belahan dunia manapun. Dengan internet kita dapat berinteraksi tanpa batasan jarak fisik, waktu, kelas ekonomi, ras, dan jarak geografis. Teknologi informasi komunikasi ini tidak bisa dipungkiri memberikan kontribusi yang signifikan pada kehidupan manusia. Mulai dari wahana teknologi informasi yang sederhana seperti perangkat radio, televisi, hingga internet dan telepon genggam dengan protocol aplikasi tanpa kabel (WAP), informasi ini tentu mengalir dengan sangat cepat dan menyeruak ke ruang kesadaran banyak orang.

Kemajuan teknologi ini adalah sesuatu yang tidak bissa dihindari dalam kehidupan, karena kemajuan teknologi informasi berjalan sesuai dengan kemajuan ilmu pengetahuan. Teknologi juga memberikan banyak kemudahan, serta sebagai cara baru dalam melakukan aktivitas manusia dewasa ini. Teknologi informasi sangat penting dalam kehidupan, teknologi informasi komunikasi (TIK) merupakan segala sesuatu apapun yang dapat membantu manusia dalam menyampaikan dan menyebarluaskan informasi dengan menggunkan media komunikasi.

Seperti yang dikungkapakan Francis Bacon, seorang pemikir dari inggris yang hidup di abad 15 yaitu "Knowledge is power" ucapannya relevan hingga kini, terutama ketika masyarakat dunia telah memasuki era teknologi informasi. Pengetahuan informasi menjadi aspek dari kehidupan yang penting bagi manusia, karena tanpa itu, masyarakat sulit untuk mengabil keputusan, memilih kebijakan, dan saling berinteraksi selayaknya zoon politikon. Christiane Amonpour, jurnalis senior $\mathrm{CNN}$ sendiri mengamini bahwa informasi menjadi kepingan sangat penting bagi hidup manusia, dengan mengatakan "information is power, informasition is securrity". http://amanpour.blogs.cnn.com/2012/04/13/5minutes-with-christiane-amanpour/. Di unduh tanggal 14 agustus 2016. Pukul 10:57 WIB

Kemajuan informasi ini adalah sesuatu yang tidak bisa dihindari dalam kehidupan ini, karena kemajuan teknologi akan berjalan sesuai dengan kemajuan ilmu pengetahuan. Setiap inovasi diciptakan untuk memberikan manfaat positif bagi kehidupan manusia. Teknologi juga memberikan banyak kemudahan, serta sebagai cara baru dalam melakukan aktivitas manusia. Manusia juga sudah menikmati banyak manfaat yang dibawa oleh inovasi-inovasi teknologi yang telah dihasilkan dalam dekade terakhir ini.

Di sisi lain, manusia tidak bisa menipu diri sendiri akan kenyataan bahwa teknologi mendatangkan malapetaka dan kesengsaraan bagi manusia modern. Kemajuan teknologi, yang semula untuk memudahkan manusia, ketika urusan itu semakin mudah maka muncul "kesepian" dan keterasingan baru, yakni lunturnya rasa solidaritas, kebersamaan, dan silahturahmi. Contohnya penemuan televisi, komputer, internet, dan handphone telah mengakibatkan kita terlena dengan dunia layar. Layar kemudian menjadi teman setia, bahkan 
kita lebih memperhatikan dunia layar kemudian menjadi teman setia. Manusia saat ini benarbenar telah menjadi budak dari teknologi. Berdasarkan survei yang dilakukan Secur Envoy (dalam Ngafifi, 2014: 35) yaitu sebuah perusahaan yang mengkhususkan diri dalam password digital, yang melakukan survei terhadap 1.000 orang di Inggris menyimpulkan bahwa mahasiswa massa kini mengalami nomophobia, yaitu perasaan cemas dan takut jika tidak bersama telepon selulernya. Hasil survei menunjukan 66 persen responden mengaku tidak bisa hidup tanpa telepon selulernya. Presentase ini semakin membengkak pada responden berusia 18 dan 24 tahun sebanyak 77 persen responden di anatara kelompok usia yang mengalami nomophobia.

Selanjutnya riset yang dilakukan Zogby Internasional (dalam Ngafifi, 2014: 35) riset yang di lakukan di Amerika Serikat menunjukan 24 persen dari 1.950 responden yang terdiri dari orang dewasa menyatakan internet memberikan dampak yang signifikan dalam hidup mereka. Menurut perusahaan riset tersebut, sebagian besar masyarakat mengatakan tidak bisa hidup tanpa internet dan membutuhkan konektivitas dengan kecepatan tinggi. Sebanyak 22 persen dari peserta penelitian itu mengakses facebook ketika berinternet dan 10 persennya mengunjungi situs Google. Ketika ditanya prediksi mereka tentang teknologi informasi masa depan, 40 persen dari responden membayangkan dalam beberapa tahun ke depan akan ditanam sebuah cip di tubuh seluruh warga dunia. Cip ini berfungsi untuk memantau kondisi kesehatan dan mendeteksi keberadaan orang tersebut. Sebagian mereka juga menyakini berbagai pekerjaan yang dilakukan manusia akan beralih ke robot. Zogby menambahkan kemajuan teknologi juga akan terasa di bidang kesehatan khususnya dalam pengembangan teknik kloning untuk menciptakan organ tubuh manusia dan sistem cell.

Perkembangan yang terjadi dengan cepat seperti diatas, membuat para ahli menyebutnya sebagai revolusi komunikasi. Perubahan yang cepat diatas didorong oleh adanya berbagai penemuan dibidang teknologi sehingga apa yang dulu merupakan kendala dalam kegiatan komunikasi, sekarang sudah terbuka lebar. Seseorang dapat berhubungan dengan seseorang atau kelompok orang tanpa dibatasi oleh faktor waktu, jarak, jumlah, kapasitas dan kecepatan. Revolusi ini tentu bukan hanya terjadi pada teori ilmu komunikasi, tetapi juga terjadi pada teknologi komunikasi. Teknologi yang dimaksud disini adalah penggunaan teknologi sebagai media dalam komunikasi manusia. Penggunaan teknologi sebagai komunikasi manusia ini banyak dipengaruhi oleh perkembanganperkembangan teknologi dari ilmu pengetahuan yang lainnya.

\section{PEMBAHASAN}

\section{Kronologis Perkembangan Komunikasi}

Manusia pada awalnya tidak mengenal konsep teknologi. Kehadiran manusia purba pada masa pra sejarah, hanya mengenal teknologi sebagai alat bantunya dalam mencari makan, alat bantu dalam berburu, serta mengolah makanan. Alat bantu yang mereka gunakan sangatlah sederhana, terbuat dari bambu, kayu, 
batu, dan bahan sederhana lain yang mudah mereka jumpai di alam bebas.

Menilik hal tesebut, pada awalnya teknologi ini berkembang secara lambat. Namun seiring dengan kemajuan tingkat kebudayaan dan peradaban manusia, perkembagan teknologi berkembang dengan cepat. Semakin maju kebudayaanya, semakin berkembang teknologinya karena teknologi merupakan perkembangan dari kebudayaan yang maju dengan pesat (Adib, 2011: 254)

Selain itu, Everett M. Rogers (1986:2) melihat bahwa teknologi komunikasi merupakan perangkat keras dalam struktur organisasi yang mengandung nilai-nilai sosial, yang memungkinkan setiap individu mengumpulkan, memproses dan melakukan saling tukar informasi dengan individu lain. Definisi Rogers tersebut menunjukkan bahwa teknologi komunikasi mempunyai beberapa karakteristik. Pertama, teknologi komunikasi berkaitan dengan perangkat keras atau alat. Kedua, teknologi komunikasi muncul dalam suatu struktur ekonomi, sosial dan politik tertentu. Ketiga, teknologi komunikasi membawa nilai-nilai tertentu dari struktur di atas. Sebuah perangkat.

Istilah media baru sampai sekarang masih menimbulkan perdebatan di kalangan ilmuwan. Kesan awal yang muncul dari konsep media baru sering diartikan secara sederhana sebagai media interaktif yang menggunakan perangkat dasar komputer. Pengertian media baru yang selanjutnya memberikan cakupan yang lebih luas seperti diungkapkan oleh Croteau (1997:12) bahwa media baru yang muncul akibat inovasi teknologi dalam bidang media meliputi televisi kabel, satellites, teknologi optic fiber dan komputer. Sementara itu, McQuail (2000 :127) membuat pengelompokkan media baru menjadi empat kategori. Pertama, media komunikasi interpersonal yang terdiri dari telpon, handphone, e-mail. Kedua, media bermain interaktif seperti komputer, videogame, permainan dalam internet. Ketiga, media pencarian informasi yang berupa portal/ search engine. Keempat, media partisipasi kolektif seperti penggunaan internet untuk berbagi dan pertukaran informasi, pendapat, pengalaman dan menjalin melalui komputer dimana penggunaannya tidak semata-mata untuk alat namun juga dapat menimbulkan afeksi dan emosional

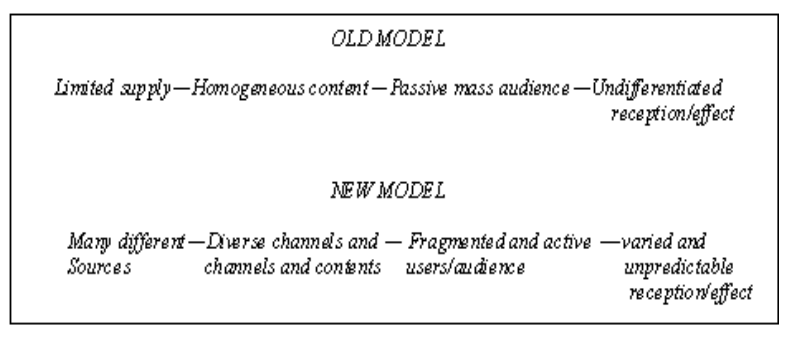

Sumber : Mc Quail, Dennis. 2000. Mc Quail's

\section{Communication}

Dari model di atas bisa terlihat jelas bahwa ketika pada model lama, sumber informasi sangat terbatas, maka pada model baru terdapat banyak sekali sumber informasi. Perubahan juga terlihat dari isi yang cenderung homogen pada model lama menjadi isi dan saluran yang menjadi sangat bervariasi dalam media baru. Sedangkan audiens diri dilihat sebagai audiens yang terfragmentasi sekaligus bersifat sangat aktif, tak lagi bersifat pasif dan massal. Respon dan efek yang sangat bervariasi sekaligus tak dapat diprediksikan. Oleh karena itu, kajian terhadap fenomena media baru haruslah selalu dilakukan untuk bisa menangkap 
dinamika yang terjadi dalam hubungan antara media dan masyarakat. Perkembangan yang terjadi dengan cepat di bidang komunikasi membuat para ahli menyebutnya sebagai revolusi komunikasi. Seseorang dapat berhubungan dengan seseorang atau sekelompok orang tanpa dibatasi oleh faktor waktu, jarak, jumlah, kapasitas dan kecepatan. Contohnya penggunaan satelit dalam komunikasi.

Everett M. Rogers dalam bukunya 'Communication Technology' membagi revolusi komunikasi ini menjadi empat era :

a. Era Komunikasi Tulisan

Era ini dimulai tahun 4000 SM pada saat bangsa Sumeria menggunakan tablet dari tanah liat, bangsa Cina meenemukan tulisan untuk percetakan buku dan bangsa Korea menemukan alat dari logam yang menggantikan huruf-huruf dari tanah. Penemuan mesin cetak merupakan awal dimulainya riwayat komunikasi massa. Dengan adanya mesin cetak ini maka pesan yang panjang dan kompleks dapat disampaikan secara simultan ke satu atau lebih kelompok khalayak yang besar.

\section{b. Era Percetakan}

Era ini dimulai dengan ditemukannya alat percetakan oleh Gutenberg pada tahun 1456 ketika untuk pertama kalinya mencetak Kitab Injil. Sekalipun mesin cetak mulai ditemukan pada tahun ini, tetapi perkembangan surat kabar berlangsung sekitar tahun 1600 .

\section{c. Era Telekomunikasi}

Di era ini, salah satu teknologi yang berkembang pada masa ini adalah film. Sejarah penemuan film berlangsung cukup panjang, disebabkan film melibatkan masalah-masalah teknik yang cukup rumit seperti masalah optic, lensa, projector, camera dan sebagainya.

d. Era Komunikasi Interaktif

Era komunikasi interaktif ditandai dengan dengan ditemukannya berbagai kemajuan teknologi seperti Komputer, Satelit, Internet dan Iain-lain. Masuknya komputer ke jaringan komunikasi telah mewujudkan berbagai kemudahan baru dalam berkomunikasi, serta masih membuka kemungkinan untuk sekian banyak peluang baru di bidang ini. Dengan bantuan komputer maka bukan saja penyimpanan, pengolahan dan penelusuran informasi berlangsung cepat dan handal, tetapi juga pertukarannya pun dapat berlangsung ke mana saja dan di mana saja.

\section{Dampak Teknologi pada Era Komunikasi Interaktif (Era sekarang)}

Dari catatan sejarah dapat kita lihat dan pelajari bahwa setiap kemajuan teknologi akan membawa pengaruh yang dominan bagi perkembangan masyarakat. Perkembangan teknologi ini selalu membawa pengaruh di bidang ekonomi, politik, sosial, dan budaya. Perkembangan yang pesat dari teknologi dewasa ini mendorong masyarakat memasuki era globalisasi yang berakibat cepat dalam menyebarkan perkembangan di satu belahan dunia ke belahan dunia yang lain. Bahkan keadaan di satu negara akan cepat menimbulkan pengaruh di negara dari belahan dunia lain. Kesemuanya ini merupakan produk dari revolusi yang terjadi di bidang komunikasi dan sarana untuk berkomunikai tersedia. 
Perubahan pesat teknologi ke arah kemajuan globalisasi ini tentu berdampak ke hampir semua aspek kehidupan masyarakat. Apabila pemanfaatan teknologi tidak diatur dengan baik, maka ada kecenderungan pemanfaatan teknologi tersebut menjadi tidak terkendali yang berakibat pada pelanggaran hukum. Era globalisasi saat ini menjadi sangat tergantung pada kemajuan teknologi yang dapat menciptakan efisiensi dengan jangkauan wilayah yang luas tanpa dihalangi oleh batas-batas negara. Salah satu wujud teknologi yang berhasil menjawab kebutuhan tersebut adalah teknologi internet (Saidin, 2004: 519)

Meluasnya pemakaian internet di segala aspek kehidupan manusia ternyata membawa konsekuensi sendiri. Artinya, bahwa era globalisasi bukan hanya sekadar era terkait dengan pasar bebas dan kebebasan untuk memperkaya negaranya masing-masing, melainkan era globalisasi adalah era ketika hak asasi manusia dan demokrasi dijunjung tinggi. Dengan keunggulan-keunggulan yang dimiliki berupa jaringan yang dapat menjangkau ke seluruh pelosok dunia, internet berhasil merubah seluruh bidang aktifitas manusia. Hal tersebut menempatkan internet sebagai media informasi yang mampu memenuhi tuntutan masyarakat global.

Perkembangan era digitalissi misalnya, hanya membutuhkan waktu tiga dekade. Media informasi menjadi ranah pertama yang terambah oleh gelombang revolusi teknologi, diantaranya dengan dunia penerbitan buku, yang dewasa ini disibukkan dengan mengkonversi buku-bukunya kedalam format digital: e-book, enhaned book, interactive book dan lain-lain.

Di Era digital ini, aktivitas manusia akan digerakan melalui serangkain teknologi digital. Teknologi ini dioperasikan dengan menekan beberapa digit (angka) yang disusun dengan berbagai urutan. Setiap individu akan memiliki identitas digital yang mampu mengenali siapa dirinya, setiap manusia sudah diberi nomor urut: melalui nomor identitas (e-KTP), nomor handphone, nomor telepone, nomor rekening listrik, rekening telepon, PIN (personal Identification Number), ATM, semuanya menggunakan sistem digital. Interaksi antarmanusia digerakkan dengan teknologi serba digital: komputer, internet, mesin ATM, telepon, handphone, dan sebagainya, semuanya digerakkan secaradigital. Kita dapat membeli sesuatu hanya dengan menggeserkan kartu ATM dan menekan beberapa nomor PIN, demikian halnya dengan membayar tagihan hotel kamar hotel, membeli tiket dan sebagainya. Pengiriman uang dapat dilakukan dalam hitungan detik hanya dengan menekan beberapa digit nilai uang yang akan dikirim dan beberapa digit nomor tujuan. Bukan uang yang dikirim, melainkan hanya sederet angka yang berpindah dari rekening satu ke rekening yang lain. Martono (2012: 292).

Kemajuan yang seperti di atas ini, berlangsung sangat cepat. Kadangkala membuat manusia tidak sempat untuk beradaptasi dengan kemajuan tersebut. Akibatnya terjadi anomi dalam masyarakat karena mereka tidak mempunyai pegangan hidup yang jelas. 
Masyarakat yang tidak mampu menguasai teknologi akan mengalami cultural lag dan akan terancam eksistensinya. Kemajuan ini ibarat dua sisi kemajuan teknologi yang memberikan banyak manfaat positif bagi manusia untuk mempermudah manusia dalam meraih kebutuhan hidupnya. Namun demikian disisi yang lain kemajuan teknologi menimbulkan efek negatif yang kompleks melebihi manfaat dari teknologi itu sendiri terutama terkait pola hidup manusia dalam dimensi sosial budaya.

a. Aspek Ekonomi

Menggunakan handphone untuk melancarkan transaksi ekonomi. Itu sudah hal yang sangat biasa kita jumpai, bahkan setiap kita bisa melakukannya, apakah itu lewat smartphone atau komputer. Pengaruh perkembangan teknologi yang sudah demikian maju ini membuat orang-orang kini memiliki kantor pribadinya sendiri-sendiri. Hanya dengan bermodalkan BB atau Android dapat melakukan segalanya, ibarat memiliki kantor sendiri. Ingin promosi, ada jejaring sosial yang bisa diakses 24 jam lewat gadget. Mau transaksi pembayaran, ada fasilitas e-banking yang tersedia disetiap bank.

b. Aspek Politik

Pemanfaatan yang paling dekat dengan kehidupan politik tentu saja teknologi penghitungan suara 'quick count'. Ini contohnya pada pilpres 2014 lalu, meskipun ada keambiguan dan polemik informasi tetapi hasil quick count bisa kita rasakan jika dipandang dari perspektif teknologinya. Yang kedua adalah penggunaan teknologi Real Time Video Conference dimana pertemuan atau rapat bisa dilangsungkan ditempat dan waktu yang berbeda, dengan menggunakan teknologi video camera. Teknologi ini seharusnya bisa meningkatkan efisiensi kerja para pejabat politik negara, yang berkilah dengan alasan studi banding ke luar negeri. Sebut saja baru-baru ini kita dihebohkan dengan perilaku anggota DPR RI Fadli Zon yang berselfie ria bersama Donald Trump

\section{c. Aspek Sosial}

Dalam kehidupan sosial, tidak perlu kita ragukan dampaknya, contohnya saja budaya masyarakat yang dulunya 'ngobrol' beramah tamah, basa-basi, dan lain-lain mendadak berubah setelah mengenal teknologi seperti facebook, twiter, dan sebagainya. Layanan ini memberikan penggunanya kebebasan untuk membuka diri dan melihat-lihat info serta privasi orang lain. Privasi bukan lagi menjadi barang mahal.

\section{d. Aspek Budaya}

Masuknya budaya asing yang kurang baik dan tidak difilter. Banyak budaya asing, baik penampilan maupun gaya hidup, yang masuk ke kelompok-kelompok masyarakat. Akibatnya terjadi pergeseran nilai-nilai dan muculnya kemerosotan moral di kalangan warga masyarakat, khususnya di kalangan remaja dan pelajar. Kemajuan kehidupan ekonomi yang terlalu menekankan pada upaya pemenuhan berbagai keinginan material, telah menyebabkan sebagian warga masyarakat menjadi "kaya dalam materi tetapi miskin dalam rohani”.

\section{Ekspektasi Perkembangan Teknologi Kedepan}

Ekspektasi perkembangan teknologi informasi kedepan akan lebih bersifat terbuka dan terjadi 
dua arah, lebih beragam, multidisipliner, serta terkait pada produktifitas kerja saat itu juga, misalanya: (a) Komputer dimana-mana, semakin portable dan mobile. Di sisi lain, seluruh peralatan yang menunjang kehidupan manusia akan mengandung komputer yang embedded. Ketersedian jaringan internet sangat tinggi karena itu merupakan akses terhadap informasi yang berlimpah. Manusia dapat bekerja, menikmati hiburan, bersosialisasi dan berkelana secara virtual keseluruh dunia tanpa harus beranjak dari tempat duduknya. Robot-robot cerdas akan melayani seluruh kebutuhan manusia. Manusia dapat melakukan berbagai hal dengan upaya fisik yang sangat minimum. (b), Berkembangnya pendidikan terbuka dengan modus belajar jarak jauh (distance learning), (c). Sharing resources antar lembaga dalam sebuah jaringan, (d). Perpustakaan dan instrumen pendidikan seperti guru dan laboratorium akan berubah fungsi menjadi sumber informasi, dan (e). Penggunaan perangkat teknologi informasi interaktif, seperti CD-ROM dan Multimedia, dalam pendidikan secara bertahap menggantikan TV dan Video.

4. Menilik pada kondisi di atas, tedensi bahwa kemajuan adalah suatu proses dehumanisasi secara perlahan-lahan sampai akhirnya manusia takluk pada teknik. Teknik-teknik manusiawi yang dirasakan pada masyarakat teknologi, terlihat dari kondisi manusia itu sendiri. Manusia pada saat ini telah begitu jauh dipengaruhi oleh teknik. Kondisi ini tentu membuat manusia mengalami ketegangan akibat penyerapan mekanismemekanisme teknik, sehingga manusia dalam pekerjaannya mengalami pergeseran, perubahan waktu dan gerak manusia akibat teknik terlepas dari hakikat kehidupan. Sebelumnya waktu diatur dan diukur sesuai dengan kebutuhan dan peristiwa-peristiwa dalam hidup manusia, sifatnya alamiah dan konkrit. Tetapi sekarang waktu menjadi abstrak dengan pembagian jam, menit, dan detik.

\section{SIMPULAN}

Dari catatan sejarah dapat kita lihat dan pelajari bahwa setiap kemajuan teknologi akan membawa pengaruh yang dominan bagi perkembangan masyarakat. Perkembangan yang pesat dari teknologi dewasa ini mendorong masyarakat memasuki era pasca-industri. Kondisi ini merupakan lanjutan dari masa praindustri dan masyarakat industri. Perbedaan utama dari masyarakat pasca-industri ini adalah penekanannya pada ekonomi di sektor jasa dan teknologi. Gejala ini sudah mulai terlihat di Amerika Serikat sejak tahun 1990, di mana telekomunikasi dan komputer menduduki posisi yang paling strategis. Diperkirakan pada tahun 2013 merupakan masa revolusi teknologi ketiga, yaitu gabungan antara komputer dan telekomunikasi.

Dampak lainnya adalah timbulnya kejahatan media internet atau lebih dikenal dengan sebutan cybercrime. Baru-baru ini berita nasional baik televisi maupun media cetak banyak yang memberitakan tentang hacker yang membobol uang nasabah bank melalui transaksi online. Seakan-akan disini penegakan hukum yang masih lemah pada bidang ITE (Informasi Teknologi Elektronik). Munculnya internet 
sebagai 'masalah kejahatan' menurut David S. Wall berbagai media berita termasuk laporan dari ancaman cybercrime tinggi tingkat - karena mereka telah selama lebih dari satu dekade dan setengah. Cukup masukkan 'ancaman cybercrime' ke Google untuk melihat berbagai liputan berita. Melihat melalui itu cakupan Anda akan menemukan bahwa sebagian besar hits reportase sensasional dan benar-benar berisi sedikit informasi substantif atau beralasan.

4. Namun, di sisi lain pemanfaatan ICT sangat membantu pemerintah dalam mengkomunikasikan dan sosialisasi kebijakan publik. Misalnya pelayanan pajak online, kemudian pelayanan BPJS online di bidang kesehatan, dan tidak lupa bidang ICT absensi elektronik dan database pegawai. Seperti dua sisi mata uang, dengan kemudahan yang diterima sudah tentu kesulitan juga akan beriringan, misalnya perubahan dari gaya hidup (lifestyle), perubahan pola dan jenis karir, perubahan isu-isu sosial uang menyebabkan banyak terjadi dinamika sosial.

5. Secara sosiologis, teknologi merupakan salah satu aspek yang turut memengaruhi setiap aktivitas, tindakan serta perilaku manusia. Teknologi mampu mengubah pola hubungan dan pola interaksi antarmanusia. Kehadiran teknologi tidak dapat dipisahkan dari kehidupan manusia. Aktivitas manusia sedikit banyak akan dipengaruhi oleh kehadiran teknologi. Teknologi telah mengubah hidup manusia. Ada banyak hal yang dijanjikan teknologi kepada manusia; janji akan kecepatan, janji akan perubahan, janji akan kemajuan, janji akan berbagai kemudahan, dan janji akan peningkatan produktivitas. Semua janji itu memang telah ditepati teknologi, namun di sisi lain, teknologi juga memberikan berbagai ancaman kepada manusia.

\section{DAFTAR PUSTAKA}

\section{BUKU}

Baran, Stanley. J. 2004. Introduction To Mass Communication : Media Litercy And Culture. New York: McGraw-Hill Companies.

Martono, Nanang (2012). Sosiologi Perubahan Sosial: Perspektif klasik, modern, postmodern, dan postkolonial. Jakarta: PT Raja Grafindo Persada

McQuail, Denis. 2000. Teori Komunikasi Massa, Suatu Pengantar. Jakarta: Erlangga.

Mc. Luhan, Marshall. 1964. Understanding Media: The extensions of man. London: The MIT Press.

Muhamad Ngafifi (2014). Jurnal Pembangunan Pendidikan: Fondasi dan Aplikasi Volume 2, Nomor 1, 2014 Jurnal Pembangunan dan Pendidikan: Fondasi dan Aplikasi

Soekanto, Soerjono 1987. Sosiologi, Suatu Pengantar. Jakarta: CV Rajawali

Rogers, Everett M. 1986. Communication Technology: The New Media in Society. New York: The Free Press.

OK.Saidin, (2004). Aspek Hukum Hak Kekayaan Intelektual, Jakarta: Raja Gravindo Persada. 


\section{NON-BUKU}

\section{Internet :}

http://amanpour.blogs.cnn.com/2012/04/13/5-

minutes-with-christiane-amanpour/. pada tanggal

14 agustus 2016. Pukul 10:57 WIB 